\title{
The House of Lords Reform White Paper and draft Bill 2011 and a simpler alternative
}

\author{
by James Hand
}

$\mathrm{T}$ he 100th anniversary of the Parliament Act 1911 has coincided with the publication of the latest attempt at reforming the composition of the House of Lords. The Coalition Government's White Paper and draft Bill on House of Lords Reform (Cm 8077) is the latest in a long line of reform attempts since the 1911 Act, which curtailed the power of the House and which in its preamble stated the intention "to substitute for the House of Lords as it at present exists a Second Chamber constituted on a popular instead of hereditary basis [although] such substitution cannot be immediately brought into operation". Over the years, committees, reports and Bills have come and gone (including those of Viscount Bryce in 1918, the Wilson Government in 1968 and Lord Home in 1978). The Life Peerages Act 1958 successfully breathed new life into the House (as the Appellate Jurisdiction Act 1876 had done with regard to Law Lords some decades before), delaying the impetus for further reform. However, the tempo increased under the New Labour Government 1997 - 2010, and there have now been four White Papers since the House of Lords Act 1999 saw the removal of all but 92 hereditary peers (which was intended to be stage one of a two stage reform process to be completed within five years (Lord Irvine, HL Deb, vol 602, col 24, June 15, 1999)).

A common theme of most, if not all, of these reports has been that the existing House of Lords does a good job and that it is the composition - not the function - that needs reform. Thus the 2011 White Paper holds that the reformed House should have the same functions and same powers as the existing House of Lords (paras 6-7), while having injected into it the 'fundamental democratic principle' that it should be wholly or mainly elected (para 13); this being, in the words used by the Prime Minister and Deputy Prime Minister in their co-authored foreword, a "unique opportunity for our country to instil greater democracy into and nine schedules over 109 pages, aims to do this through a series of convoluted provisions and transitional arrangements. However, rather than setting out a package of proposals representing radical "incremental reform" (para 1), the government's aim of maintaining the status quo in terms of function and power, while addressing the desire for a more democratic house, could better and more simply be met through an evolutionary, yet swifter, reform.

\section{A FALSE CHOICE AND A SIMPLER PROPOSAL}

In posing a choice between a wholly or mainly elected House of Lords (para 22), the government is posing a potentially false choice. Election and appointment are no more mutually exclusive states than election and hereditament (as outlined in "House of Lords Reform: Many Anniversaries and a False Dichotomy?" [2009] 4 Web JCLI). The Weatherill amendment to the House of Lords Act 1999 saw the introduction of elected hereditary peers (whereby, following the general abolition of the hereditary peers' right to sit and as a transitional measure until final reform is settled, hereditary peers from each of the parties and the cross-benches elected 10 per cent of their then number to remain with a further 15 hereditary peers elected by the whole house to act as deputy speakers and the like). A modified replication of this concept for life peers, with recurrent elections and where, while the proportion of cross-benchers is fixed, the numbers of party peers change according to, for example, either general or local election results could provide a combination of the benefits of election and appointment while mitigating some of the problems with both. Such a relatively minor evolutionary change to the membership of the House would be better attuned to maintaining the current position as to role and powers than the government's proposed revolutionary one (which risks unintended, if not unforeseen, consequences). 


\section{MATTERS OF SIZE AND COMPOSITION}

The current White Paper proposes that the new House of Lords should consist of 300 full-time, salaried members (para 12). The draft Bill is framed on the basis that 80 per cent of the members would be elected with the remaining 20 per cent being independent appointments approved by a Statutory Appointments Commission (although the White Paper also considers the alternative of all 300 being elected; in either case they would be joined by 12 Church of England bishops (proportionately cut down from the current 26)). While there is an argument for a salaried and full-time house to be smaller than the current size of nearly 800 (not least to keep the costs down), the White Paper does not address the comparative value of full-time and potentially part-time membership (beyond the statement that " $[t]$ he Government expects members of the reformed House to be full-time Parliamentarians") and nor does it address, in any depth, the current attendance when contemplating the size of the House.

In the era of the fostering of the Big Society, it seems somewhat perverse to professionalise and severely narrow down a body of highly talented, experienced and costeffective volunteers, with members who, while not receiving the honour of a peerage, would receive nigh-on $£ 900,000$ (at today's prices) in salary over their likely 15 year term (members would be limited to serving one term, which is expected to be three five-year Parliaments, in the reformed House with the salary being greater than that received by members of the devolved legislatures (paras 24 and 111)).

A House allowing part-time members would not, as at present, need to be salaried, and would allow the members to retain their active links with the real world and thus better prepare them should they leave the House after a number of years (a 15 year hiatus in any career could be problematic unless members are expected to enter new careers, for example lobbying, after their service).

The White Paper's focus on average attendance - that while there are 789 members the average daily attendance in the $2009 / 2010$ session was only 388 - is flawed in a number of ways. Firstly, while the average is drawn from the 2009/2010 session, the 789 figure is as of May 2011 and thus includes well over 100 new peers created since the end of that session. Furthermore, such a focus ignores both the breadth of experience that the House has within it and the nature of averages: "300 full-time members" could conceivably be able to "fulfil the same range of duties as the current average daily attendance of 388" (para 12), but they would not have the same experiences (both past and current) as, and are unlikely to be able to fulfil those duties to the same level as, a greater number of part-time members who attend when their expertise and interest are most of use. Based on the 2009/2010 attendance figures (and excluding those peers who died or were introduced in the period) the average peer attended 57 per cent of the sessions (or $60 \%$ if those who did not attend at all are excluded). The average daily attendance of 388 must thus comprise very different people on different days and constraining the House to 300 full-timers excludes many more regular attendees than the juxtaposition of 300 and 388 suggests.

Under the evolutionary system suggested above (whereby life peers are elected by their fellows, with a fixed number of cross benchers and the parties' numbers varying according to election results, ie "Weatherill (as amended) life peers"), the virtues of part-time membership could be retained, the remuneration costs would not be increased and the size of the House could be capped at a higher level providing a greater range of representation. If a cut-off was placed at 300, based on the 2009/10 figures it would see peers who attended 73 per cent of the time excluded whereas a cut-off of 500 would take the attendance down to 44 per cent (of course there would be no cut-off as such as the life peers would be elected but it is an approximation of the lost experience at various sizes). Some form of cap on the size of the House is necessary for practical reasons, a Leader's Group having been convened by Lord Strathclyde to try to deal with the issue, and this system would allow for regular modulation - obviating the problem demonstrated by Hazell and Seyd (in "Reforming the Lords: the numbers" [2008] Public Law 378 at 383) of keeping a House of life peers proportional through new creations after each election.

\section{THE POSITION OF MINISTERS}

The White Paper proposes that ministers should only be drawn from the elected and transitional members (para 67), presumably because the appointed element are independent. However, in order to provide the flexibility of appointing ministers (which has been used to notably good - and less good - effect in recent years) they then propose that there will be ad hoc members who will have membership only for the duration of their ministerial appointment (para 68). A Weatherill (as amended) life peers system would not need such an ungainly provision as a similarly small number of peers could be created during a Parliament and then face election among their peers in what would be the usual way. Nor would it, as the government's proposal appears to do, preclude the albeit rare possibility of independents acting as ministers.

\section{ELECTORAL SYSTEMS AND TRANSITION}

The "Weatherill (as amended) life peers" system would meet the Coalition Agreement's commitment to a system of proportional representation for the reformed House of Lords as the number of party members would change proportionately to the election result used (which would most likely be the general election but could alternatively be local or European elections). Limited appointments could be made during each Parliament, as at present, but there would be no need for the Blairite and Coalition mass 
creations following changes of government. This indirect election system would be more of a filter on the current process of appointment, providing an element of proportionality, and thus should not to any great degree involve the problems of attracting a sufficient calibre of candidate which is often leveled against an elected subordinate House. Furthermore, while there would be a democratic element injected into the House, the indirect election of appointees to the peerage and the presence of cross-benchers would restrict any claims to a greater mandate and allow the balance between the Houses to be preserved.

The White Paper's proposals are far more radical (with a number of peers, including Baroness Bothroyd, referring to it as abolition - see eg HL Deb vol 719, col 1172, June 21, 2011). It would see either 80 per cent or 100 per cent of the members being elected by single transferable vote elections to the House, with one third of the House elected at each election. The elections would take place on the same day as the general election, risking confusion (as happened with the Scottish elections). While doing so would be cheaper than holding the elections on a separate date, it is unnecessarily expensive to the meet the aim of proportionality which could be achieved far more cheaply by elections among peers under the Weatherill (as amended) life peers' system. Furthernore, such a system would also be simpler than the government's proposal to create distinct House of Lords constituencies which will be almost, but not fully, co-extensive with the European regions (para 43) and avert voter fatigue.

As the White Paper proposes that one-third of the House would be elected at each general election, there would need to be some transitional arrangements (paras 69-86). The Weatherill (as amended) life peers system would not require any transitional arrangements; it could be implemented swiftly and could even be introduced as an amendment to Lord Steel's House of Lords Reform Bill currently, and it seems perennially, before the House (Lord Steel has introduced versions of the bill in the 2006/2007, 2007/2008 and 2008/2009 sessions). The Bill seeks to reform leave of absence and abolish hereditary peer byelections, and originally sought to create and guide an independent appointments commission. An amendment, akin to the 1999 Weatherill amendment, could easily be made and constitute final reform. The White Paper outlines three options for transition, none of which admittedly last as long as that in the first option in the previous administration's last White Paper (Cm 7438), which would take until the middle of the century, but it is nonetheless still a lengthy period, taking 15 years to take its final form (with elected and either a decreasing proportion of current members or, under option 2, all current members sitting side-by-side until then). A larger, potentially part-time, voluntarily House comprising much of the same members as now would avoid such an elongated transition.

\section{CONCLUSION}

The draft Bill arguably transforms the House of Lords into a democratically legitimate second chamber although the need or desirability for the second chamber to be democratically elected is by no means undisputed - but it does so at an unnecessarily high cost (both financial and experiential) and level of complexity. The government could meet their stated aims through a simpler and faster change which could see many of the recognised virtues of the current House maintained, a democratic element introduced, the problem of a growing House solved and reform completed, not just under way, by the time of the next election.

- This article is an extended version of a submission to the Parliamentary Joint Committee on the draft House of Lords Reform Bill.

\section{James Hand}

Associate Senior Lecturer, School of Law, Portsmouth Business School, University of Portsmouth. 